\title{
ANALISIS PENGARUH WAKTU PEMANASAN TERHADAP KADAR OKSALAT DALAM BAYAM HIJAU (Amarantus hybridus) DENGAN MENGGUNAKAN METODE SPEKTROFOTOMETRI UV-Vis
}

\author{
Rusvirman Muchtar*, Yusi Fudiesta, Sukrido, Devi Windaryanti \\ Jurusan Kimia, Fakultas Matematika Dan Ilmu Pengetahuan Alam \\ Universitas Jenderal Achmad Yani, Cimahi - Bandung \\ *Corresponding author email : ir.muctar@gmail.com
}

\begin{abstract}
Green spinach( Amaranthus hybridus) was utilized as complement of food as vegetable as spinach is cooked through instillation process with stewed (clear spinach vegetable) and slicing (spinach vegetable). Besides contains a lot of nutrient, spinach also contain substance anti nutrient which is oxalate what do get to precipate calcium and forms calcium oxalate that can't be absorbed by body, so formed by causative dissolvable salt sediment its appearance calculus disease. After been done research to spinach vegetable of trick second upon with at poaching was gotten by content oxalate as big as 0,108 $\mathrm{g}$ (without condiment) and $0,112 \mathrm{~g}$ (with condiment) with optimum time 3 minutes. On brew with slicing oxalate content $0,112 \mathrm{~g}$ (without condiment) and 0,125 $\mathrm{g}$ (with condiment) with maximum time 5 minutes. Measurement oxalate content utilizes $U V$ Vis's Spectrophotometer method on wavelength $345 \mathrm{~nm}$. Oxalat's rate in green spinach lies under letal dose is contemned according to BADAN POM RI 2012 (6 - $8 \mathrm{~g}$ ).
\end{abstract}

Keywords: Spinach, Oxalate, Spectrophotometry Uv-Vis

\begin{abstract}
ABSTRAK
Bayam hijau (Amaranthus hybridus) sudah dimanfaatkan sebagai pelengkap makanan berupa sayuran bayam dimasak melalui proses pemanasan dengan rebusan (sayur bayam bening) dan ditumis (sayur bayam). Selain mengandung banyak gizi, bayam juga mengandung zat anti gizi yaitu oksalat yang dapat mengendapkan kalsium dan membentuk kalsium oksalat yang tidak dapat diserap oleh tubuh, sehingga terbentuk endapan garam yang tidak dapat larut yang menyebabkan munculnya penyakit batu ginjal. Setelah dilakukan penelitian terhadap sayur bayam dari kedua cara di atas dengan di rebus didapatkan kandungan oksalat sebesar $0,108 \mathrm{~g}$ (tanpa bumbu) dan 0,112 g (dengan bumbu) dengan waktu optimum 3 menit. Pada pemasakan dengan penumisan kadar oksalat 0,112 $\mathrm{g}$ (tanpa bumbu) dan $0,125 \mathrm{~g}$ (dengan bumbu) dengan waktu maksimum 5 menit. Pengukuran kadar oksalat menggunakan metode Spektrofotometer UV-Vis pada panjang gelombang $345 \mathrm{~nm}$. kadar oksalat dalam bayam hijau berada di bawah letal dosis terendah menurut Badan POM RI 2012 (6-8 g).
\end{abstract}

Kata Kunci : Bayam (Amaranthus hybredus), Asam oksalat, Spektrofotometer UV-Vis

Submitted on: 7 April 2017

Accepted on: 1 Desember 2017

DOI: https://doi.org/10.25026/jsk.v1i8.81

\section{PENDAHULUAN}

Bayam (Amarantus hybridus) termasuk jenis sayuran daun yang sudah lama dikenal dan dibudidayakan secara luas di Indonesia. Bayam merupakan salah satu jenis sayuran komersil yang mudah diperoleh di setiap pasar, baik pasar tradisional maupun passar modern. Chamjangali et al (2006) melaporkan bahwa sayur bayam mengandung kadar oksalat sebanyak 3,8 ppm, penelitianpenelitian terbaru juga menunjukan bahwa 
kandungan kadar oksalat bertambah atau semakin banyak larut apabila dibiarkan terlalu lama atau sayuran dipanaskan kembali.

Pemanasan dengan cara perebusan suhu tinggi, selain mengurangi kadar oksalat dapat juga menurunkan beberapa nutrisi penting dalam bahan sayur, dan penurunan kadar oksalat sampai $52,1 \%$ bila dimasak pada suhu $60^{\circ} \mathrm{C}$ selama satu jam. Menurut Sentra Informasi Keracunana Nasional dan Badan POM RI (2012) rata-rata dosis letal asam oksalat pada manusia dewasa 15-30 gram. Dosis letal terendah yang pernah di laporkan adalah 6-8 gram (fitriani dkk., 2016). Menurut Jiang et al (1996), kandungan oksalat yang tinggi dalam urin atau komponen darah dapat menyebabkan penyakit ginjal, kekurangan vitamin, penyakit usus dan hiperoksaluria. Selain itu oksalat merupakan asam kuat sehingga dapat mengiritasi saluran pencernaan terutama lambung. Jenis-jenis bayam yakni bayam hijau dan bayam merah, Bayam hijau adalah jenis bayam yang biasa dikonsumsi, bentuk daunnya yang kecil dan lembut sangat digemari oleh masyarakat, bayam ini juga disebut bayam cabut (Amaranthus Tricolor. L).terdiri dari 2 spesies yaitu : 1).Amaranthus hybridrus caudatus.L, memiliki daun agak panjang dengan ujung agak runcing, berwarna hijau kemerahan atau merah tua dan bunganya tersusun dalam rangkaian panjang berkumpul pada ujung batang, dan 2).Amaranthus hybridrus paniculatus.L, memiliki dasar daun yang lebar sekali, berwarna hijau, rangkaian bunga panjang tersusun secara teratus dan besar-besar pada ketiak daun (Rukmana, 1994). Bayam merah atau blitul rubrum. Cirinya yaitu memiliki batang dan daun yang berwarna merah. Memiliki tinggi batang sekitar 0.4-1 mtr dan bercabang, batang lemah dan berair, daun bertangkai, berbentuk bulat telur serta pangkal runcing berwarna merah. Manfaat utama bayam merah adalah memperlancar sistem pencernaan, menurunkan resiko terkena kanker, mengurangi kolestero dan anti diabetes (Purwaningsih, 2007).

Manfaat dari kandungan nutri bayam diantaranya ; a) melawan sel kanker (adanya vitamin A dan C, serat, asam folat, 13 flavonoid, dari hasil penelitian, menunjukan kandungan tersebut dapat menurunkan resiko kander $34 \%$ terutama kanker payudara, kanker rahim, kanker prostat, kanker kulit, b).Sumber Anti-inflamasi, bayam mengandung sifat alkalinitas yang tinggi sehingga membuat sayur ini pilihan yang sempurna bagi penderita penyakit inflamasi, seperti rheumatoid arthritis dan osteoarthritis, c).Menutrisi tulang dan sendi, Kandungan kalsium yang terdapat dalam bayam mampu untuk menguatkan semua tulang pada tubuh. Sehingga dapat meminimalisir terjadi pengeroposan pada tulang atau osteoporosis sedini mungkin dengan rutin mengkonsumsi bayan, d). Mengurangi risiko penyakit kardiovaskular, bayam merupakan sumber folat yang baik, yang dapat mengurangi homosistein, asam amino yang ditemukan dalam darah. Oleh sebab itu penelitian ini diarahkan terhadap waktu pemanasan yang baik pada sayur bayam dengan proses perebusan (sayur bayam bening) dan prosaes penumisan (sayur bayam tumis) menggunakan bumbu masak dan tanpa bumbu masak. Pengukuran kadar oksalat menggunakan metoda Spektrofotometer UV-Vis. 

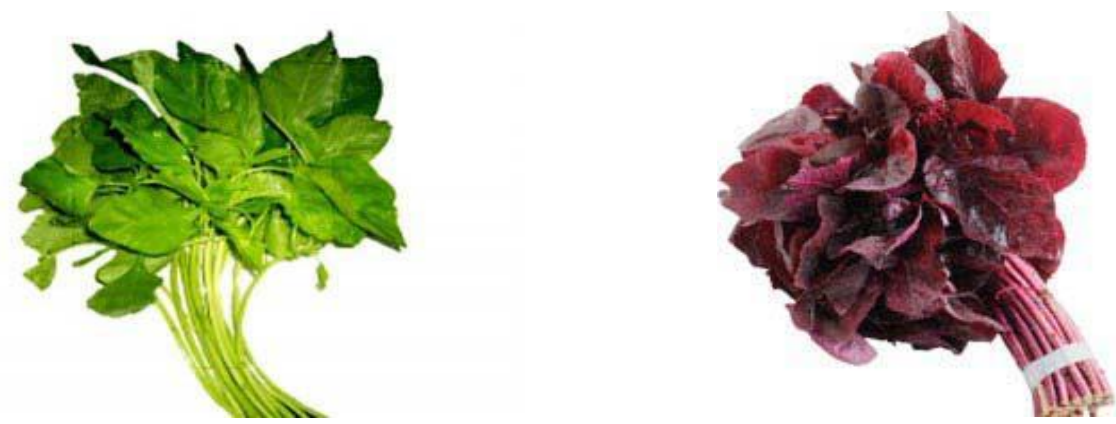

Gambar 1. Bayam (a) Hijau dan (b) Merah (Jamaluddin, 2012)

Tabel 1 Kandungan gizi pada 100 gram bayam hijau dan bayam merah. (Lingga,2010)

\begin{tabular}{ccccccccc}
\hline $\begin{array}{c}\text { Komponen } \\
\text { Gizi }\end{array}$ & $\begin{array}{c}\text { Bayam } \\
\text { Hijau }\end{array}$ & $\begin{array}{c}\text { Bayam } \\
\text { merah }\end{array}$ & $\begin{array}{c}\text { Komponen } \\
\text { Gizi }\end{array}$ & $\begin{array}{c}\text { Bayam } \\
\text { Hijau }\end{array}$ & $\begin{array}{c}\text { Bayam } \\
\text { merah }\end{array}$ & $\begin{array}{c}\text { Komponen } \\
\text { Gizi }\end{array}$ & $\begin{array}{c}\text { Bayam } \\
\text { Hijau }\end{array}$ & $\begin{array}{c}\text { Bayam } \\
\text { merah }\end{array}$ \\
\hline Energi & $36 \mathrm{kcal}$ & $51 \mathrm{kcal}$ & Fosfor & $67 \mathrm{mg}$ & $111 \mathrm{mg}$ & Air & $86,9 \mathrm{~g}$ & $86,0 \mathrm{~g}$ \\
Protein & $3,5 \mathrm{~g}$ & $4,6 \mathrm{~g}$ & Zat besi & $3,9 \mathrm{~g}$ & $2,2 \mathrm{~g}$ & Bgn larut & $71 \%$ & $71 \%$ \\
Lemak & $0,5 \mathrm{~g}$ & $0,6 \mathrm{~g}$ & Vit. A & $6,09 \mathrm{~g}$ & $5,80 \mathrm{~g}$ & & & \\
Karbohidrat & $6,5 \mathrm{~g}$ & $10,0 \mathrm{~g}$ & Vit.B1 & $6,5 \mathrm{~g}$ & $10,0 \mathrm{~g}$ & & & \\
Kalsium & $267 \mathrm{mg}$ & $368 \mathrm{mg}$ & Vit.C & $267 \mathrm{mg}$ & $368 \mathrm{mg}$ & & & \\
\hline
\end{tabular}

\section{METOLOGI PENELITIAN}

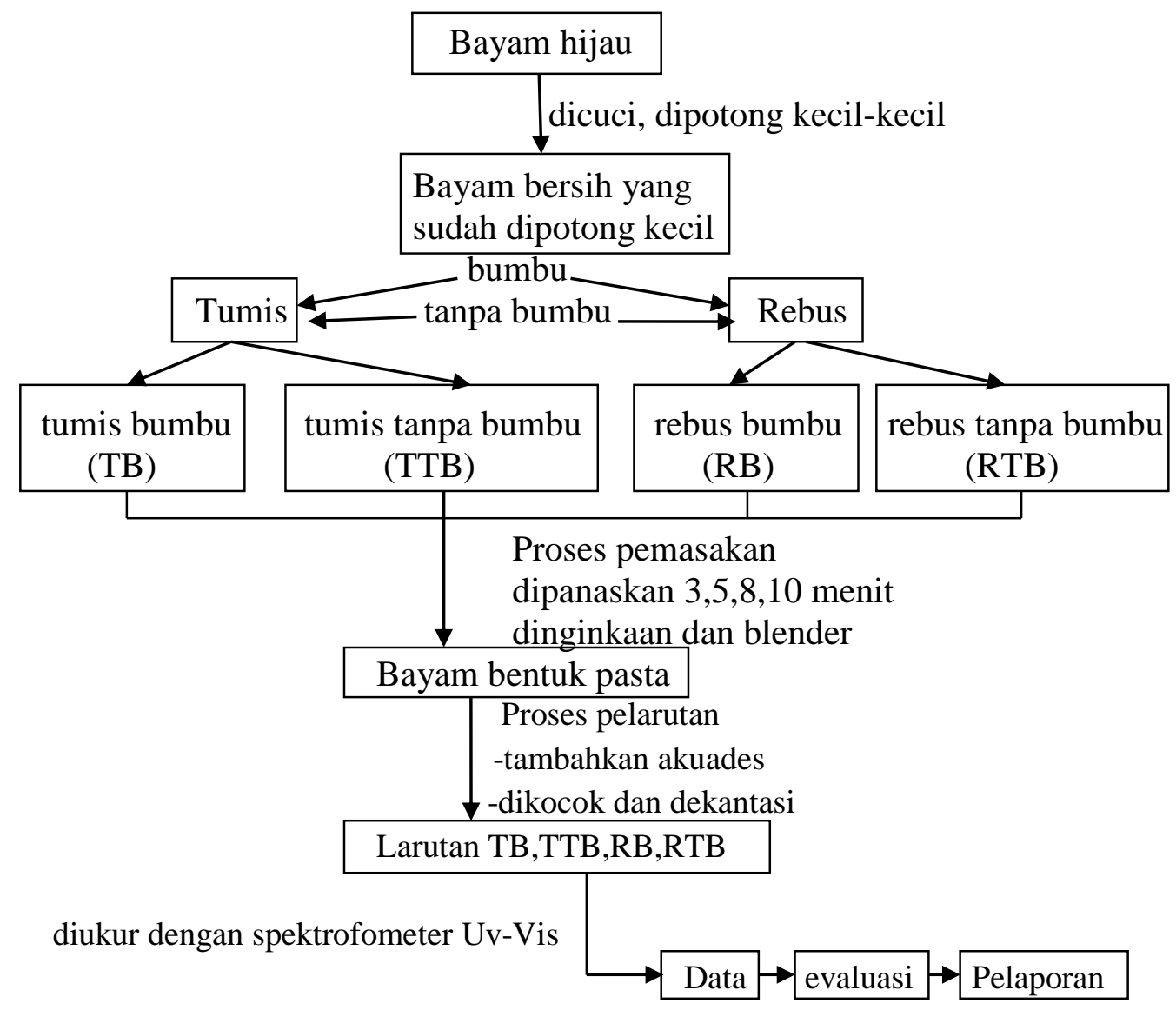




\section{Alat dan Bahan}

Alat-alat gelas laboiratorium, $\mathrm{pH}$ meter, spektrofotometer UV-Vis T60 PG Instrumen, stop watch, hotpalte, timbangan analitis dan teknis, sentrifuge dan bahan-

\section{HASIL DAN PEMBAHASAN}

\section{Penentuan Panjang Gelombang Maximum}

bahan kimia, aquades, bayam hijau, Asam asetat, besi (II) aluminium sulfat, kalium bromat, kalium iodida, natrium asetat, natrium oksalat

\section{kurva panjang gelombang maksimum}

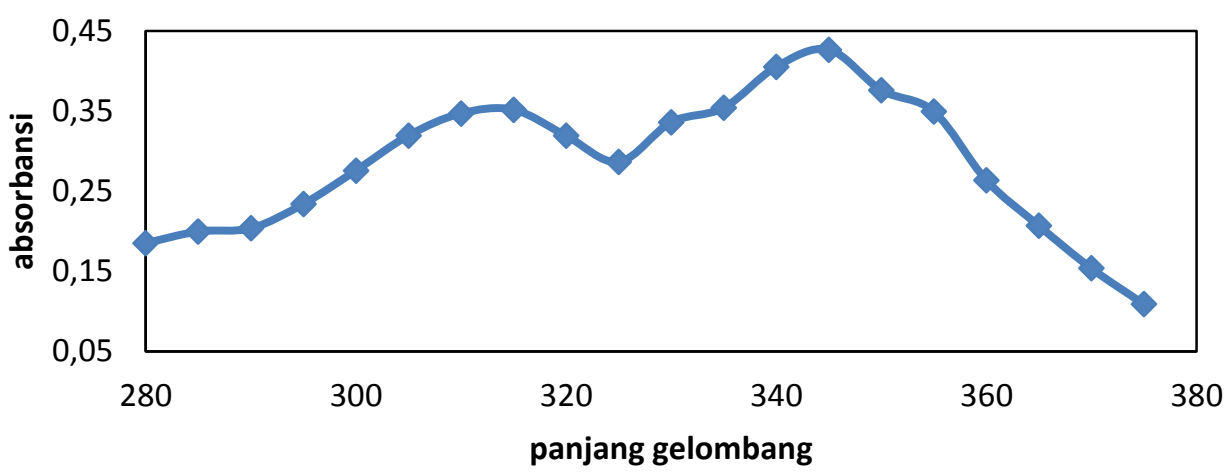

Gambar 3 kurva panjang gelombang maksimum

Pembuatan kurva standar oksalat.

\section{Kurva standar oksalat}

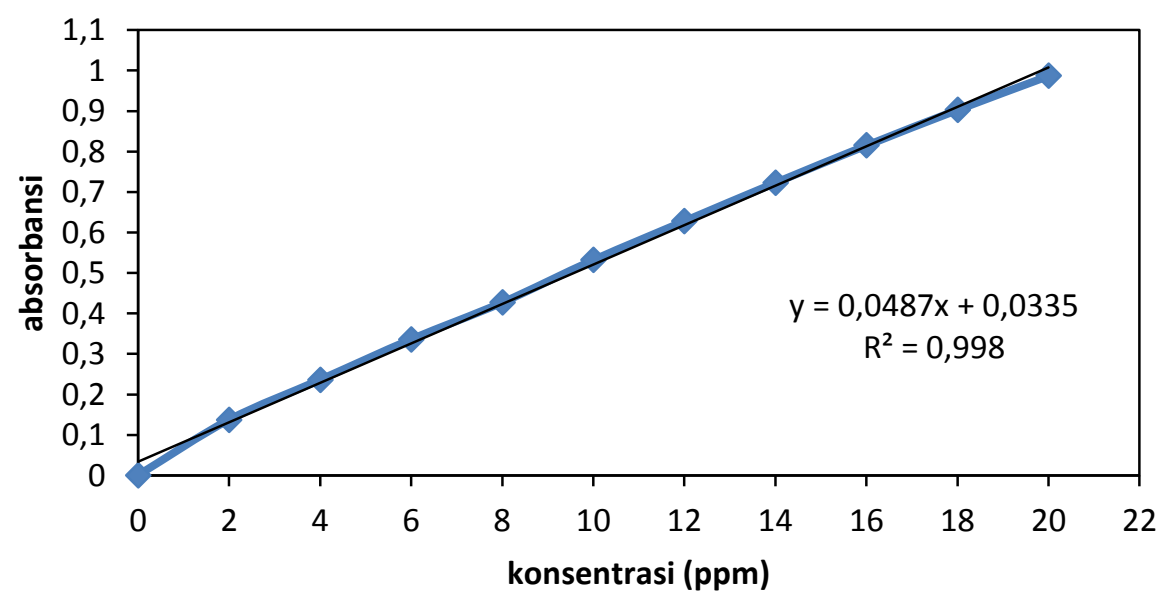

Gambar 4. Kurva standar oksalat 


\section{Penentuan Kadar Oksalat Dalam Bayam Hijau}

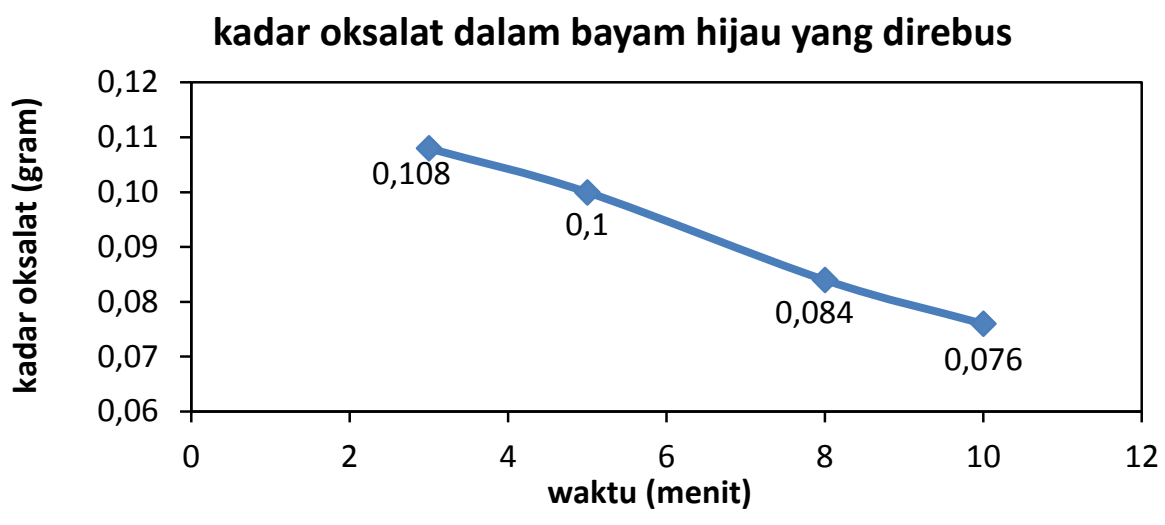

Gambar 5 Kadar oksalat dalam bayam hijau yang direbus

\section{kadar oksalat dalam bayam hijau yang direbus tambah bumbu}

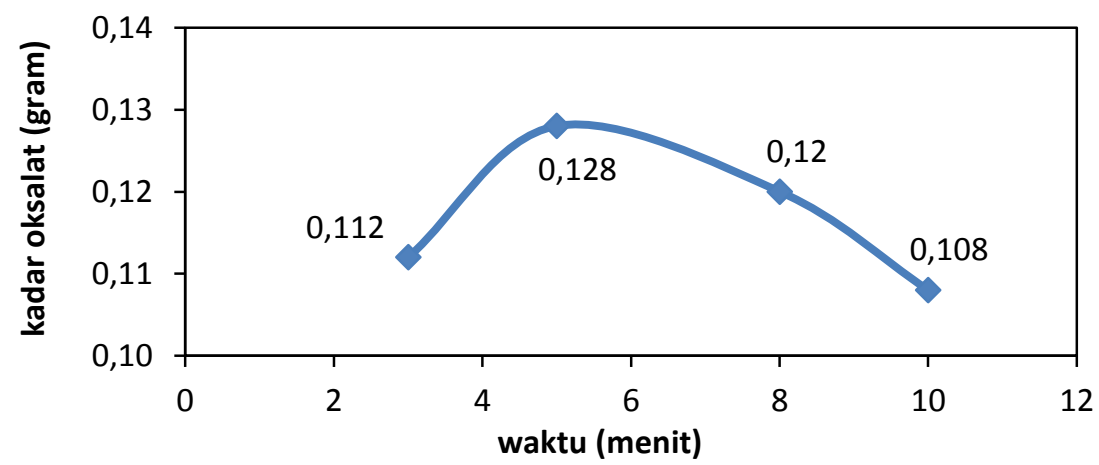

Gambar 6 Kadar oksalat dalam bayam hijau yang direbus tambah bumbu

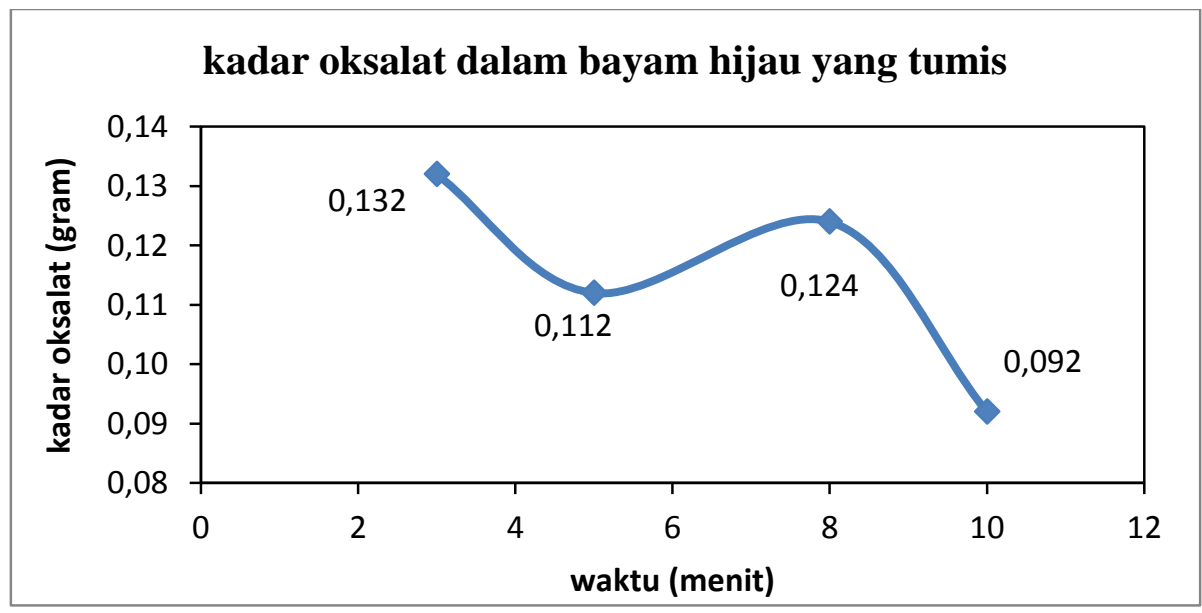

Gambar 7. Kadar oksalat dalam bayam hijau yang ditumis tanpa bumbu 


\section{kadar oksalat dalam bayam hijau yang tumis tambah bumbu}

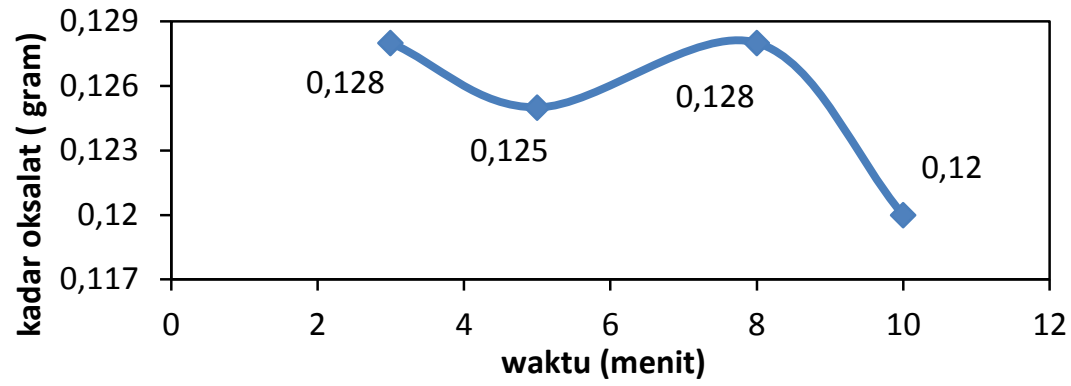

Gambar 8. Kadar oksalat dalam bayam hijau yang tumis tambah bumbu

\section{Pembahasan}

Pada gambar 3 terlihat panjang gelombang spektrofoto meter maksimum pada $345 \mathrm{~nm}$, panjang gelombang maximum ini akan digunakan dalam penentuan kadar oksalat dalam bayan hijau sebagai sampel. Untuk menghitung kadar oksalat dalam bayam melalui persamaan regresi linier $\mathrm{y}=0,487 \mathrm{x}+$ 0,0335 dengan koefisien korelasi 0,998 yang diperoleh dari perhitungan kurva standar oksalat gambar 4.

Kandungan oksalat dalam sayur bayam yang direbus tanpa bumbu diperlihatkan pada gambar 6, dimana waktu pemanasan maksimum pada 3 menit, kadar oksalat 0,108 g direbus tanpa bumbu (sayur bayam bening) dan $0,112 \mathrm{~g}$ direbus pakai bumbu (sayur bening bayam) dengan waktu pemanasan maksimum 3 menit. Bila waktu pemanasan diperpanjang atau memasaknya dengan waktu lebih dari 3 menit, bayam akan layu atau menggumpal kemungkinan kandungan gizi berkurang atau hilang sedang kandungan oksalat juga berkurang dalam hal ini sebaiknya bayam jangan dikonsumsi sebagai makanan sayuran.

Pemasakan sayur bayam melalui penumisan atau sayur tumis bayam diperoleh kandungan oksalat $0,132 \mathrm{~g}$ tanpa bumbu dan $0,128 \mathrm{~g}$ pakai bumbu seperti pada gambar 5 dan gambar 8 dengan waktu maksimum permanasan juga 3 menit. Waktu penumisan di perpanjang juga menjadikan sayur tumis bayam menjadi layu dan menggumpal dengan kandungan oksalat berkurang dan kemungkinan zat gizi hilang atau berkurang. Sayur bening bayam dan sayur tumis bayam waktu yang baik untuk di konsumsi selama 3 menit dan kandungan oksalat masih berada di bawah batas ambang yang diizinkan Badan POM RI 2012 yaitu $6-8 \mathrm{~g}$, dengan demikian kedua macam sayuran tersebut layak di konsumsi sebagai makanan pelengkap dari makanan 5 sehat 4 sempurna.

\section{KESIMPULAN}

Berdasarkan penelitian yang telah dilakukan pengaruh waktu pemanasan bayam hijau terhadap kadar oksalat dapat disimpulkan sebagai berikut:

1. Pada proses pemanasan dengan direbus semakin lama kadar oksalatnya semakin rendah, waktu pemanasan optimumnya yaitu pada 3 menit dengan kadar oksalat sebesar 0,108 gram. Perebusan dengan bumbu diperoleh waktu optimumnya yaitu pada 3 menit dengan kadar oksalat sebesar $0,112 \mathrm{~g}$.

2. Pada proses pemanasan dengan ditumis waktu pemanasan 
optimumnya yaitu 5 menit dengan kadar oksalat sebesar $0,112 \mathrm{~g}$. Penumisan dengan bumbu diperoleh waktu optimumnya yaitu 5 menit dengan kadar oksalat sebesar $0,125 \mathrm{~g}$

3. Kadar oksalat dalam bayam hijau yang dihasilkan berada di bawah letal dosis terendah menurut Badan POM RI 2012 yaitu 6-8 $\mathrm{g}$.

\section{DAFTAR PUSTAKA}

[1]. Ahmad, D. 2008. Manfaat Tanaman Obat. Penerbit Edsa Mahkota. Jakarta.

[2]. Chamjangali, M.A. Keley, V. Bagherian, G. 2006. Kinetic Spectrophotometric Method For The Determination Of Trace Amounts Of Oxalate By An Activation Effect. Analytical Sciences. Vol 22. Hal 333-336.

[3]. Fitriani, H. Nurlailah.Rakhmina, D. 2016. Kandungan Asam Oksalat Sayur Bayam. Jurnal Analis Kesehatan. Kemenkes Banjarmasin. Vol 2(2). Hal 51-55.
[4]. Jamaluddin, 2012,Pengetahuan Masyarakat Tentang Sayur Bayam, http://elib.unikom.ac.id/files/dish1/619/jbptu nikompp-gdl-Jamaluddin-30944-10unikom_j-i. Diakes pada 6 Desember 2016.

[5]. Jiang, Z.L, M.X.Zhao, L.X.Liao. 1996. Catalytic Spectrophotometric Methods For Determination of Oxalic Acid. Analytical Chemical. Acta 320: 139-143.

[6]. Ramdani, S. 2010. Bayam Jadi Pilihan Usaha. Cet 2. Sarjana Ilmu Pustaka. Bandung.

[7]. Rukmana, R. 1994. Bayam, Bertaman \& Pengolahan Pascapanen. Kanisius. Yogyakarta.

[8]. Santoso, A.M. 2013. Distribution Of Calcium Oxalate Cristal, Reduction Of Oxalates, And The Effect Of Cultivation Method On Its Formation In Some Vegetable. Seminar Nasional X Pendidikan Biologi FKIP UNS. Vol 10. No. 2 